\title{
Flexural cracks in fibre-reinforced concrete beams with fibre-reinforced polymer reinforcing bars
}

\author{
Enes Krasniqi ${ }^{1}$, Assoc. Prof. Domagoj Damjanović ${ }^{2}$ Prof. Naser Kabashi \\ ${ }^{1}$ University of Prishtina, Faculty of Civil Engineering, enes.krasniqi@uni-pr.edu \\ ²University of Zagreb, Faculty of Civil Engineering, domagoj.damjanovic@grad.unizg.hr \\ ${ }^{3}$ University of Prishtina, Faculty of Civil Engineering, naser.kabashi@uni-pr.edu
}

\begin{abstract}
There are several reasons why civil and structural engineers may need to use FRP reinforcement (fibre reinforced polymer) in concrete. The primary reason is durability, but other reasons include electromagnetic neutrality, high strength, and lightweight. The use of fibre-reinforced polymer composites, as replacement for steel reinforcement in concrete structures, is a widespread practice in many countries. The unique characteristic of FRP as a material not susceptible to corrosion makes it particularly suitable in a variety of situations. Due to generally low elastic modulus and poor bond, the use of FRP results in larger crack widths, especially when beams are reinforced with GFRP bars. The aim of this research is to use fibre-reinforced concrete (FRC) in order to reduce crack widths. The paper provides results for 16 beams (three samples per set for GFRP and two samples per set for steel reinforcement) tested under four point bending. Based on the applied methodology, the existing codes are reviewed, compared and modified, so as to enable their calibration in accordance with appropriate results.
\end{abstract}

Key words: RC beams, GFRP, CFRP, FRC, fibre coefficients, crack width

\section{Pukotine od savijanja u gredama od betona ojačanog vlaknima s armaturnim šipkama od vlaknima ojačanog polimera}

\section{Sažetak}

Nekoliko je razloga zbog kojih građevinski inženjeri koriste FRP armaturu (polimer ojačan vlaknima - FRP) u betonu. Primarni razlog je trajnost, a ostali razlozi uključuju elektromagnetsku neutralnost, veliku čvrstoću i malu masu. Upotreba polimernih kompozita ojačanih vlaknima kao zamjena čelične armature za betonske konstrukcije široko je rasprostranjena praksa u mnogim zemljama. Jedinstvena karakteristika FRP materijala da nije osjetljiv na pojavu korozije, čini njihovu primjenu posebno prikladnom u različitim situacijama. Zbog općenito malog modula elastičnosti i slabe prionjivosti, upotreba FRP-a rezultira većim širinama pukotina, posebno kod greda ojačanih GFRP šipkama. Tendencija ovih istraživanja je upotreba betona ojačanog vlaknima (FRC) kako bi se smanjile pukotine. Rad uključuje rezultate ispitivanja 16 greda (s GFRP ili čeličnom armaturom) ispitanih savijanjem u četiri točke. Na temelju primijenjene metodologije pregledani su, analizirani i uspoređeni postojeći propisi te su modificirani kako bi se kalibrirali u skladu s odgovarajućim rezultatima.

Ključne riječi: RC grede, GFRP, CFRP, FRC, koeficijenti vlakana, širina pukotine 


\section{Introduction}

Corrosion is one of the most common causes of deterioration in reinforced concrete structures [1]. The alkaline nature of concrete is of crucial importance for protection of steel reinforcement againts aggressive environment, ensuring formation of a passive oxide layer on the surface of reinforcement. Nonetheless, when exposed or when the alkaline environment is neutralized, conventional steel corrodes and leads to spalling of concrete cover [2]. Corrosion may occur when chloride ions penetrate through concrete into reinforcement and cause rupture of the protective oxide layer. Deicing salts (parking lots, highway structures, marine structures) are the major factor of chloride induced corrosion. Current methods of preventing corrosion such as permeability or protection of reinforcing bars, are costly or potentially infeffective in the long run.

The use of fibre reinforced polymer (FRP) as reinforcement in concrete is becoming quite attractive among engineering professionals. FRP could be applied in structures in/or near aggressive environments, in places where good quality concrete can not be achieved, and in slender structural elements. FRP bars are nowadays commercially available and utilized in many countries. A number of recent studies have highlighted the benefits of FRP use as replacement of conventional steel as flexural reinforcement [3]. There are many reasons why engineering community may need to use FRP reinforcement in concrete. Although the primary reason is durability, FRP is also electromagnetically neutral while steel reinforcement can interfere with magnetic field. In addition, the high strength of FRP reinforcement can be utilized to reduce congestion of reinforcement in certain applications. However, compared to conventional steel, most types of FRP bars possess a relatively low elastic modulus and develop a relatively poor bond to concrete. This results in larger crack widths and deflections under service loads compared to beams reinforced with conventional steel bars [4]. Additional disadvantages are related to linear elastic behaviour with no yield [2].

The addition of fibres as micro-reinforcement in composite materials is a wellknown concept in various fields of engineering. Fibre Reinforced Concrete may be defined as concrete containing relatively short, discrete, discontinuous fibres that are uniformly distributed and randomly oriented. The fibres tend to bridge the cracks, control crack development, and prevent occurrence of large cracks [5]. This feature of fibres is beneficial for enhancement of low elastic modulus yielding effects on beams reinforced with FRP, in particular those reinforced with GFRP bars [6]. The purpose of this study is also to assess whether the addition of fibres can improve cracking resistance in concrete in terms of stress and strain. The design of beams reinforced with GFRP is typically governed by serviceability requirements (deflection and crack width), which emphasize the bond behaviour of GFRP bar 
in concrete as the main parameter in design, because bond controls the cracking behaviour $[7,8]$. Beams reinforced with GFRP bars reveal excessive crack widths $[9,10]$ and, for that purpose, three sets of identical beams (in terms of geometry and bar reinforcement) were tested in order to improve understanding of the fibre addition effect (plain concrete vs FRC). The cracking responses of specimens were studied to clarify improvements that may result from addition of fibres as reinforcement.

\subsection{Research Methodology}

Several analytical calculations and FEM analysis were first conducted using various approaches in order to define influential areas where main deflection and cracks will appear. This preceded placement of the reference linear variable differential transformer (LVDT) at locations where the main reference crack and maximum deflections occur, as shown in figure below.

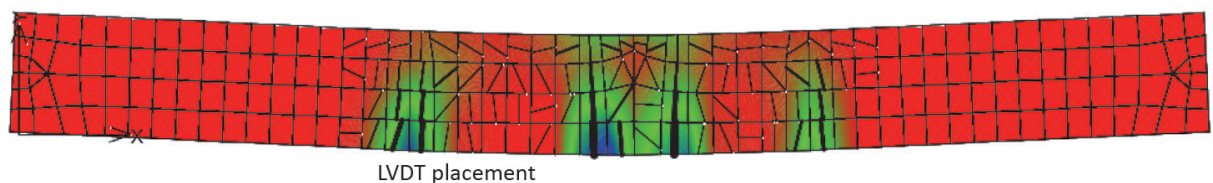

Figure 1. Influential zones as reference for LVDT placements

After curing in laboratory conditions, specimens were carefully placed in the determined frame, where they were subjected to a four-point bending load, as shown in Figure 3 and Figure 8 . The tests were performed using the multifunctional console control MCC8, and so several characteristics were recorded for each beam, such as displacement, crack width, deflection, and applied force. The experimental and analytical results were compared and used to define new corrective bond coefficients, which were calibrated using results obtained during experimental investigations. Based on a relatively wide range of bond coefficients for GFRP bars, beams with plain concrete were calibrated in the first step, and the results obtained were used to estimate bond coefficients for FRC, as illustratively presented in Figure 2. 


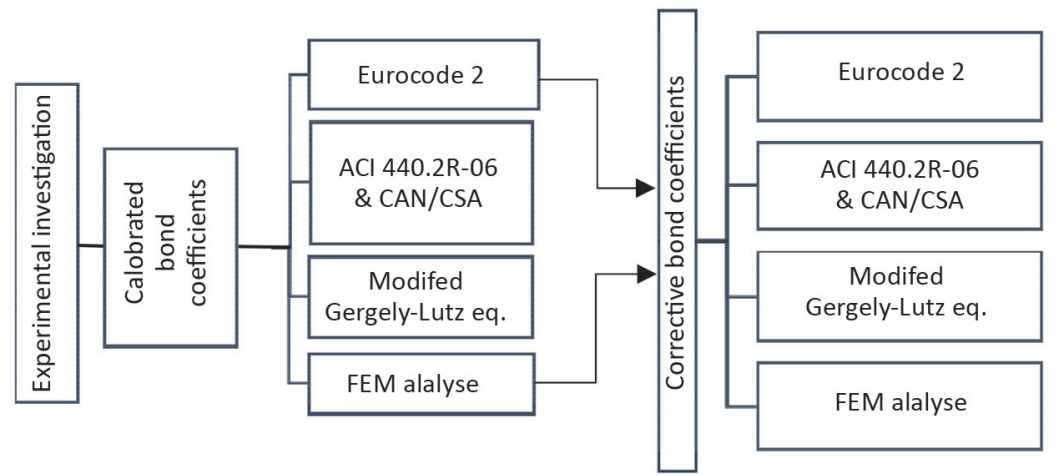

Figure 2. Flowchart with approximation of bond coefficients

\section{Experimental campaign}

Concrete mix design was prepared with the requested class of concrete C 30/37. The following specimens were cast at the same time: three plain-concrete specimens and six prisms with FRC. The FRC used in this investigation contained micro polypropylene fibres at a volume fraction of $0.063 \%$ or $600 \mathrm{gr} / \mathrm{m}^{3}$. Polypropylene fibres applied in the investigation had a tensile strength of $650 \mathrm{MPa}$, elastic modulus of $3.5 \mathrm{GPa}$, and were $12 \mathrm{~mm}$ in length. The quantity of fibres was adopted based on manufacturer's recommendations in order to maintain cost-effectiveness of FRC.
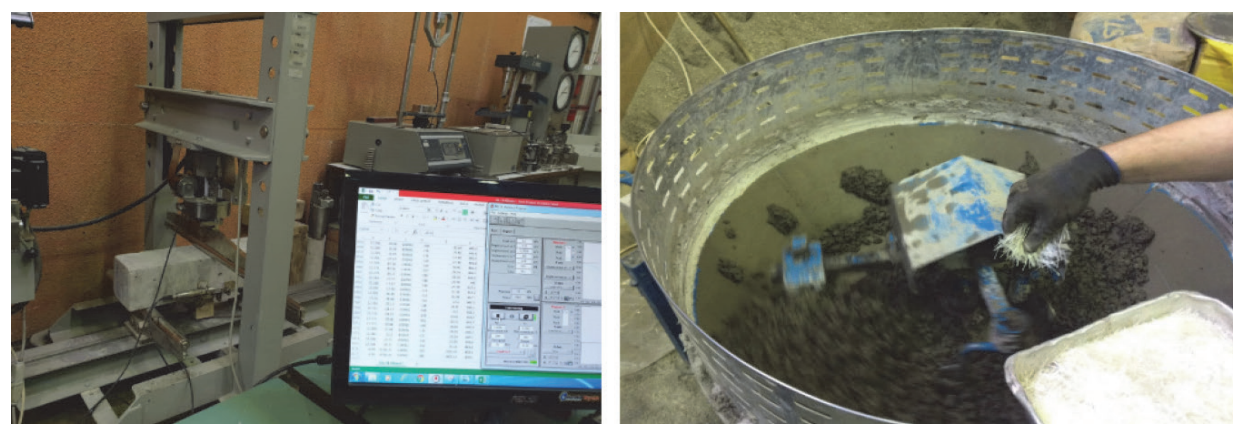

Figure 3. Preparation and examination of FRC specimens

The testing was performed according to guidelines given in EN 14651: 2005 using prismatic specimens $(150 \times 150 \times 600 \mathrm{~mm})$. Three-point bending test setup was used, as presented in figures 3 and 4 . The specimens were notched at mid span and the notch was $25 \mathrm{~mm}$ in height [11]. 

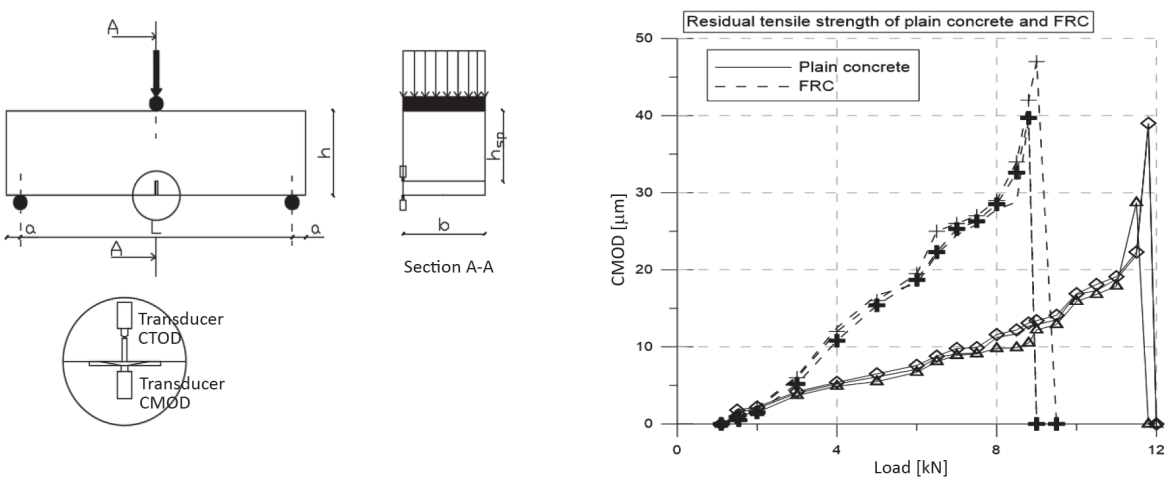

Figure 4. Test setup for flexure test of notched specimens and effects of fibres in relation to load-CMOD

The loading was performed using the displacement control. The method allows measurement of force-displacement respectively force-CMOD (crack mouth opening displacement) relations. Transducers used for CMOD and CTOD measurements were installed on specimens, as shown in Figure 4. During the test, the loading rate was controlled over CMOD.

The GFRP bars were formed using pultrusion methods, and contained glass fibres in a resin matrix. Mechanical properties of GFRP bars were examined based on ASTM D 7205 [12].
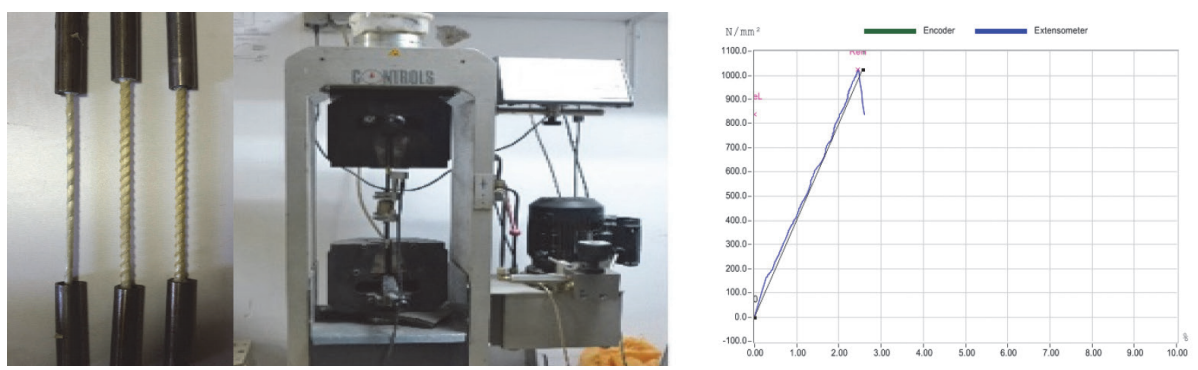

Figure 5. Specimens, testing and determination of mechanical properties of GFRP bars

The edges of bars were embedded inside engraved metallic cylinders in order to avoid constriction or shear stress of the GFRP bars, as shown in Figure 5. Properties of conventional steel were used from known parameters based on the previous research works for S500. FRP bars used in our research were GFRP (helically grooved) bars the mechanical properties of which are presented in Table 1. 
Table 1. Mechanical properties of GFRP and conventional bars

\begin{tabular}{|c|c|c|c|c|c|c|}
\hline $\begin{array}{c}\text { Bar } \\
\text { type }\end{array}$ & $\begin{array}{c}\text { Bar } \\
\text { size }\end{array}$ & $\begin{array}{c}\text { Elastic modulus } \\
{[\mathrm{GPa}]}\end{array}$ & $\begin{array}{c}\text { Tensile strength } \\
{[\mathrm{MPa}]}\end{array}$ & $\begin{array}{c}\text { Design tensile } \\
\text { strength } \\
{[\mathrm{MPa}]}\end{array}$ & $\begin{array}{c}\text { Yield strain } \\
{[\%]}\end{array}$ & $\begin{array}{c}\text { Rupture strain } \\
{[\%]}\end{array}$ \\
\hline GFRP & $\phi 6$ & 50.59 & 1022 & 731.3 & $/$ & 1.2 \\
\hline GFRP & $\phi 8$ & 54.3 & 1108.2 & 802.7 & $/$ & 2.34 \\
\hline Steel & $\phi 8$ & 200 & 500 & 434.8 & 2 & 10 \\
\hline
\end{tabular}

The set of reinforced concrete beams consisted of sixteen specimens (three specimens per set for GFRP and two specimens for conventional steel, as shown in Table 2) with various reinforcement and rectangular cross section, $130 \mathrm{~mm}$ in width and $220 \mathrm{~mm}$ in height. Each reinforced beam specimen contained two reinforcing bars ( $\phi 6 \mathrm{~mm}$ or $\phi 8 \mathrm{~mm}$ ) placed at the bottom, while two identical bars were placed as top reinforcement for each specimen.

Table 2. Test specimens

\begin{tabular}{|c|c|c|c|c|c|c|c|}
\hline 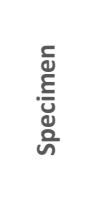 & 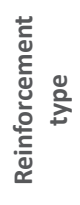 & $\begin{array}{l}\bar{E} \\
\underline{E} \\
\frac{N}{\tilde{N}} \\
\frac{1}{\pi} \\
\infty\end{array}$ &  & 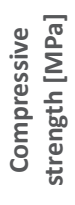 & 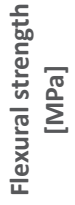 & 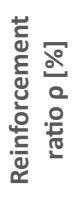 & 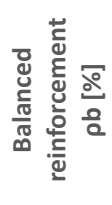 \\
\hline S1G1 & GFRP & $\phi 6$ & Plain & 36.6 & 3.96 & 0.22 & 0.50 \\
\hline $\mathrm{S} 2 \mathrm{G} 2$ & GFRP & $\phi 8$ & Plain & 37.1 & 3.53 & 0.40 & 0.45 \\
\hline S1S1 & Steel & $\phi 6$ & Plain & 36.6 & 3.56 & 0.22 & 1.59 \\
\hline S2S2 & Steel & $\phi 8$ & Plain & 38.1 & 3.53 & 0.4 & 2.10 \\
\hline S1G1F & GFRP & $\phi 6$ & FRC & 36.6 & 3.37 & 0.22 & 0.50 \\
\hline $\mathrm{S} 2 \mathrm{G} 2 \mathrm{~F}$ & GFRP & $\phi 8$ & FRC & 37.1 & 3.47 & 0.40 & 0.45 \\
\hline
\end{tabular}

The cross section geometry and the number of reinforcing bars were chosen to represent various reinforcement states (low reinforcement and balanced reinforcement ratio). The specimen geometry, boundary conditions and random reinforcing scheme can be seen in figures 6 and 7 . 


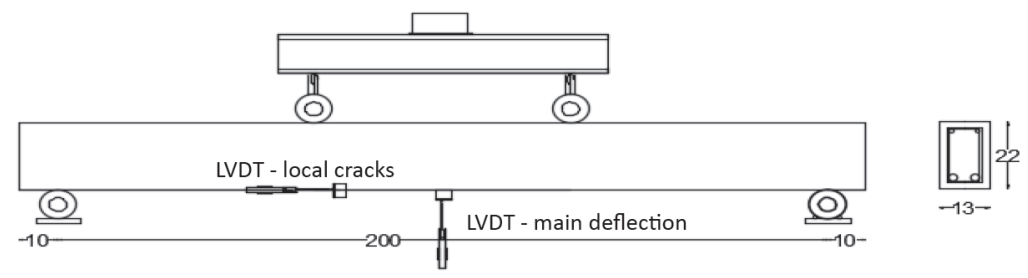

Figure 6. Beam details, instrumentation and geometrical parameters of concrete beams
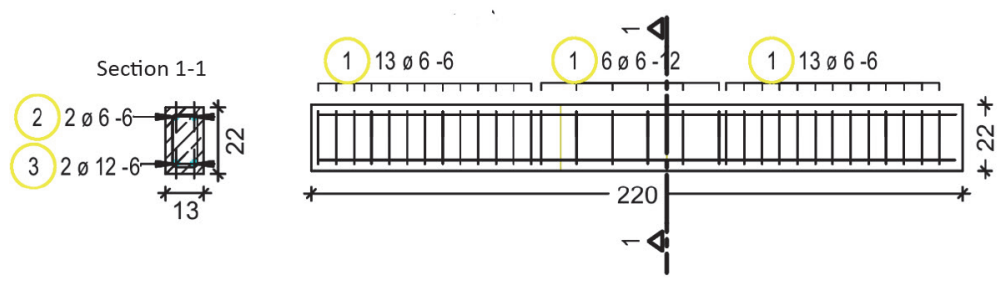

Figure 7. Beam reinforcement scheme

Testing set up for beams is shown in Figure 6, LVDT's were placed in critical positions to enable analysis of cracks and deflections. Thus, one LVDT was positioned on the right side to measure the width of the first flexural crack under concentrated force, while the other was placed in mid span to measure deflection.
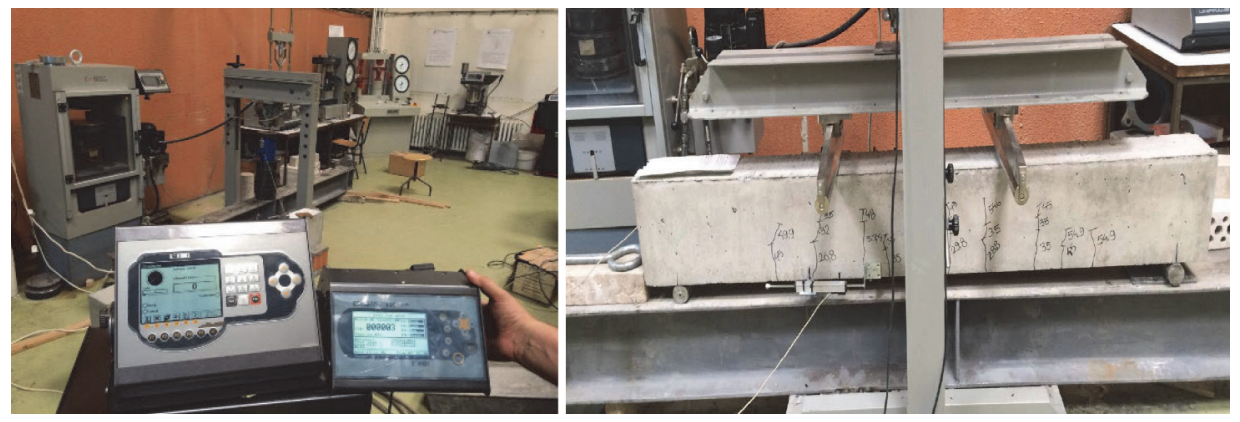

Figure 8. Instrumentation calibration and beam examination

All beam specimens were tested under four-point bending over a mid span of 200 $\mathrm{cm}$ (Figure 8). The load was applied using a $200 \mathrm{kN}$ hydraulic actuator with the constant stroke-controlled rate of $200 \mathrm{~N} / \mathrm{s}$. The actuator and LVDTs were connected to a data-acquisition unit for continuous recording of the readings. 


\section{Crack width modelling}

\subsection{Adhesion coefficients $k_{b}$, and $k_{1}$ and introduction of fibre coefficients $\mathbf{k}_{5}, \mathbf{k}_{\mathrm{fb}}, \mathbf{k}_{\mathrm{fb}}^{\prime}$.}

The terms $k_{b}$, and $k_{1}$ are coefficients that account for the degree of bond between the FRP bar and the surrounding concrete. The adhesion coefficient $k_{b}$ refers to $\mathrm{ACl} 318$ [13] respectively Gergely-Lutz equation, while $\mathrm{k}_{1}$ is the bond coefficient for crack width calculation according to Eurocode 2 [14]. The average value of $k_{b}$ was found to range from 0.60 to 1.72 depending on the type of FRP, fibre type, resin, and type of surface treatment, while $k_{1}$ ranged from 0.8 to 1.6. [17] Some typical predicted values for GFRP bars, $\mathrm{k}_{\mathrm{b}}$, cited in $\mathrm{ACl}$, ranged between 0.8 and 1.80 . However, the $\mathrm{ACl}$ Codes and Manuals suggest that designers assume a value of 1.2 for GFRP bars unless more specific information is available for a particular bar. The $\mathrm{ACl}$ Committee 440 [15] modified the Gergely-Lutz equation for the use with concrete members by incorporating the effects of different bond and mechanical properties of FRP.

$w=2.2 \frac{f_{f r p}}{E_{f r p}} \cdot \frac{h_{2}}{h_{1}} \cdot k_{b} \sqrt[3]{d_{c} \cdot A}$

where:

w - crack width

When the stress is represented as a function of moment, the Gergely-Lutz equation can be used to plot the moment versus crack width.

$w=2.2 \frac{M}{A_{f r p} E_{f r p} \cdot j \cdot d} \cdot \frac{h_{z}}{h_{2}} \cdot k_{b} \sqrt[3]{d_{c} \cdot A}$

Pre-cracking behavior of beams is not linear as suggested in Gergely-Lutz equation, because the crack width began to increase with an increase in moment only at the cracking moment, where the first cracking formed. A modification to the Gergely-Lutz equation was used to include the pre-cracking behavior as a crack form when the tensile strength of concrete is reached [6].

$w=2.2 \frac{M-M_{c r}}{A_{f r p} E_{f r p} \cdot j \cdot d} \cdot \frac{h_{z}}{h_{2}} \cdot k_{b}^{\prime} \sqrt[3]{d_{c} \cdot A}$ 
Eurocode 2 crack width equation is strain based and can be adopted directly for the crack width determination of FRP RC elements [18]. The difference in bond characteristics is implemented through coefficient $k_{1}$ and for the long term stress via parameter $\mathrm{k}_{\mathrm{t}}$.

$\mathrm{W}=\mathrm{s}_{\mathrm{r}, \max } \cdot\left(\varepsilon_{\mathrm{sm}}-\varepsilon_{\mathrm{cm}}\right)$

The strain difference in this expression can be calculated as for an ordinary concrete. However, a new coefficient needs to be introduced in the crack spacing formula where $k_{5}$ is the additional factor that accounts for the effects of fibres.

$\mathrm{s}_{\mathrm{r}, \mathrm{m}}=\mathrm{k}_{3} \mathrm{c}+\mathrm{k}_{1} \mathrm{k}_{2} \mathrm{k}_{4} \mathrm{k}_{5} \frac{s}{p_{p, \text { eff }}}$

Fibre effect coefficients incorporate the ratio of tensile strength $f_{c t m}$ and residual tensile strength $f_{t k \text {,res }}$ where calibration values are determined through experimental investigation. Also, fibre coefficients $\mathrm{k}_{\mathrm{fb}}$ and $\mathrm{k}_{\mathrm{fb}}{ }^{\prime}$ were implemented for Gergely-Lutz and modified Gergely-Lutz equation.

$w=2.2 \frac{M-M_{c r}}{A_{f r p} E_{f r p} \cdot j \cdot d} \cdot \frac{h_{z}}{h_{2}} \cdot k_{b}^{\prime} k_{f b}^{\prime} \sqrt[3]{d_{c} \cdot A}$

An additional aim of this study is to develop bond models that can accurately predict the response, based on improvement of crack width for GFRP reinforced concrete beams. The ATENA software was used to perform FEM simulations and compare numerical outputs with experiment results; the corresponding bond models were calibrated. A bond model is used to develop behaviour of reinforcement relating to concrete, in the aspect of slip (m) versus bond strength (MPa).

\section{Experimental results and discussion}

Bond coefficients for beams reinforced with steel bars were close to 1 , as expected, because the original Gergely-Lutz equation is based on the steel-concrete relation. A reduction in the bond coefficient means improvement of bond characteristics of the reinforcing bar as compared to steel. Bond characteristics are represented with $\mathrm{k}_{1}$ in Eurocode 2 and values larger than 0.8 denote worse bond characteristics related to steel. Sets with minimum or balanced GFRP reinforcement $\left(S_{1} G_{1}\right.$ and $\left.S_{2} G_{2}\right)$ exhibited inferior bond characteristics related to steel. 
The corresponding values of bond coefficients versus ratio of applied moment (M) and ultimate moment $\left(\mathrm{M}_{\mathrm{u}}\right)$ are shown for different phases of loading in Figure 9 where the bond coefficient of modified Gergely-Lutz differs quite clearly. The approximation happens only in the pre-cracking phase, while in the following phases it differs from reference values. An increase in fibre ratio affects the pre-cracking behavior but the ratio taken for this experiment did not achieve the nominal fibre content in order to influence the post-cracking behaviour [19]. Adding small fraction of fibres did not influence the post-crack behavior. On the contrary, few parameters such as volume fraction, fibre length, and modulus of elasticity, tended to improve brittle failure. Fibres on the fracture surface did not bridge the cracks and behaved quite inactively like voids or defects in concrete matrix.
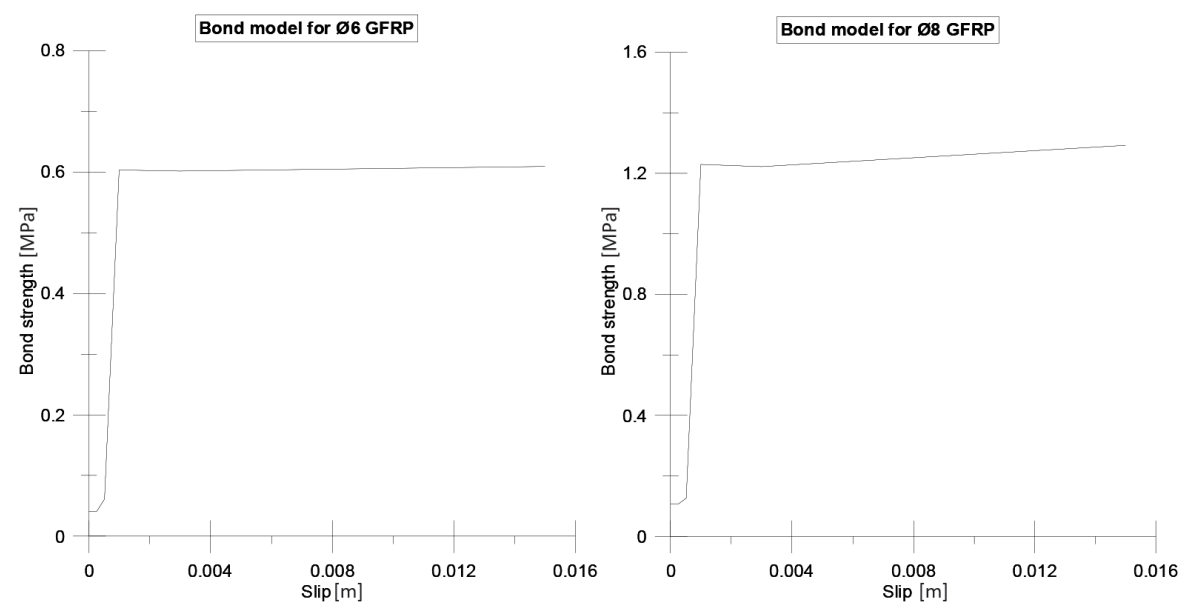

Figure 9. Corrective bond coefficients versus $M / M_{u}$

Table 3. Calculated fibre coefficients

\begin{tabular}{|c|c|c|c|c|c|c|c|}
\hline \multirow[b]{3}{*}{ SET } & \multirow[b]{3}{*}{ Bar type } & \multicolumn{3}{|c|}{ "SLS" State } & \multicolumn{3}{|c|}{ (M/Mu - $75 \%)$} \\
\hline & & \multicolumn{3}{|c|}{ Fibre coefficients } & \multicolumn{3}{|c|}{ Fibre coefficients } \\
\hline & & $\mathrm{k}_{5}$ & $\mathrm{k}_{\mathrm{fb}}$ & $\mathrm{k}_{\mathrm{fb}}{ }^{\prime}$ & $\mathrm{k}_{5}$ & $\mathrm{k}_{\mathrm{fb}}$ & $\mathrm{k}_{\mathrm{fb}}^{\prime}$ \\
\hline S1G1F & $\varnothing 6$ GFRP-F & 1.2 & 1.1 & 1 & 0.75 & 0.9 & 0.85 \\
\hline S1G1F & $\emptyset 8$ GFRP-F & 0.9 & 0.95 & 0.85 & 1 & 0.9 & 0.9 \\
\hline
\end{tabular}


Ø6 GFRP- CORRECTIVE BOND COEFFICIENTS

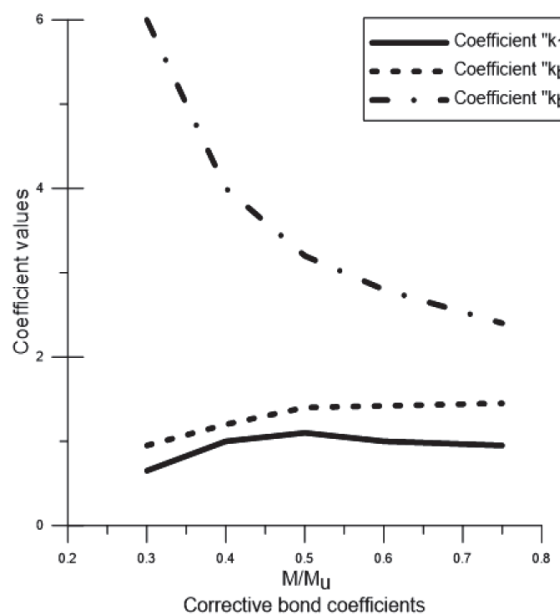

Ø8 GFRP- CORRECTIVE BOND COEFFICIENTS

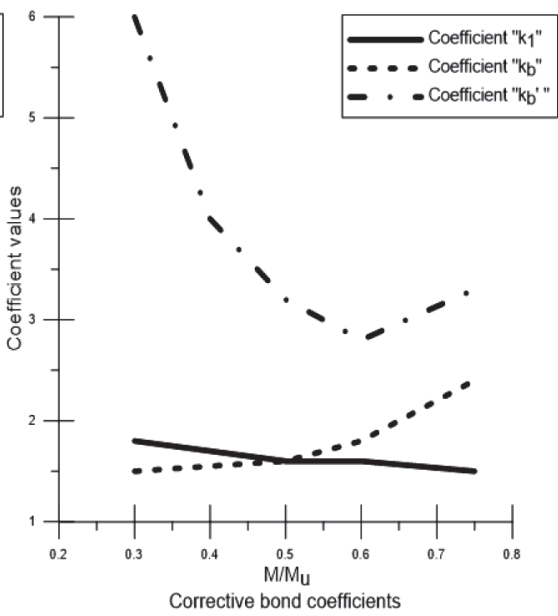

Figure 10. Bond model- beams with $\emptyset 6$ and $\emptyset 8$ GFRP reinforcement

Based on experimental results, the corresponding bond models were developed as a function of bond strength and slip, as shown in figure above.

\section{Conclusions}

The cracking behavior of plain and polypropylene FRC beams with GFRP and reference conventional steel was measured and the following conclusions were drawn from the experimental investigation results:

Beams with balanced reinforcement ( 7 to $10 \%$ deviation) are in good correlation with reference values of bond coefficients, while beams with minimum reinforcement have shown inferior bond characteristics.

The analytical approach for crack calculation has shown adaptation through bond coefficients, except for the modified Gergely-Lutz equation that has shown compliance in the pre-cracking phase only.

An attempt was made to incorporate through fibre coefficients the effects of fibres with variation of residual tensile strength as yield effect, as shown in Table 4. The addition of small amount of polypropylene fibres has shown contrary effects, as related to pre-yield cracking behavior.

The effect of fibres can be obtained in the final stage of bearing capacity with symbolic influence ( $1 \%$ to set S1G1F and $6 \%$ to set S2G2F), as related to reference beams without fibres. 


\section{References}

[1] Penttala, V., "Causes and mechanisms of deterioration in reinforced concrete", Failure, Distress and Repair of Concrete Structures, Structures,Woodhead Publishing, pp.3-31. doi:10.1533/9781845697037.1.3.

[2] Fib Bulletin 40 "FRP reinforcement in RC structures", 2007,pp.31-51.

[3] Nanni, A., "North American Design Guidelines for Concrete Reinforcement and Strengthening Using FRP: Principles, Applications and Unresolved issies, "Constructions and Building Materials, V.17, No. 6-7,2003, pp.439-446.

[4] Houssam Toutanji, Yong Deng "Deflection and crack-width prediction of concrete beams reinforced with glass FRP rods", Construction and Building Materials, Volume 17, Issue 1, 2003, pp. 69-74, doi: 10.1016/S0950-0618(02)00094-6.

[5] COIN Project report 66-2015 "Structural FRC - Design approach and experimental results" 2015, pp.3-5.

[6] Lee, K.; Jansen, D.; Berlin, K. et al. "Flexural Cracks in Fibres-Reinforced Concrete Beams with Fibre-Reinforced Polymer Reinforcing Bars" ACl Structural Journal, V. 107, No. 3, May-June 2010.

[7] CSA-S806-02, Design and Construction of Building Components with Fibre Reinforced Polymers" Canadian Standards Association, Ontario, 2002.

[8] CAN/CSA s6-14, "Canadian Highway Bridge Design," Canadian Standards Association, Mississauga, ON, Canada, 2014, pp.875

[9] Kabashi, N., et al., "Flexural Behaviour and Cracks in Concrete Beams Reinforced with GFRP bars," ICPIC 2018, Washington DC, 2018, doi:10 1007/978-3-319-78175-4_79

[10] Chidananda S. H, Khadiranaikar. R. B.: Flexural Behaviour of Concrete Beams Reinforced With GFRP Rebars; International Journal of Advance Research, Ideas and Innovations in Technology, Volume 3, Issue 5, 2017

[11] EN 14651, Test method for metallic fibre concrete-Measuring the flexural tensile strength (limit of proportionality (LOP), residual). European Committee for Standardization, B-1050 Brussels, September 2007

[12] ASTM D 7205 Standard Test Method for Tensile Properties of Fibre Reinforced Polymer Matrix Composite Bars

[13] ACl 318-19 Building Code Requirements for Structural Concrete

[14] Eurocode 2: Design of concrete structures

[15] 440R-07 Report on Fibre-Reinforced Polymer (FRP) Reinforcement for Concrete Structures 
[16] CNR-DT 2032006; Guide for Design and Construction of Concrete Structures Reinforced with Fibre-Reinforced Polymer Bars" National Research Council, Rome; Italy, 2006.

[17] Singh, B. Sh. Analysis and Design of FRP Reinforced Concrete Structures: New Delhi, McGaw-Hill, 2014.

[18] CEB-FIP Technical report “FRP reinforcement in RC structures” bulletin 40, pp.70.

[19] Sahith Gali, Kolluru V. L. "Evaluation of crack propagation and Post-cracking Hinge-type Behavior in the Flexural Response of Steel Fibre Reinforced Concrete", International Journal of Concrete Structures and Materials, Vol.11, No.2, pp.365-375, June 2017

[20] Zemour, N. et al., "Experimental Study on Splice Strength of Glass Fibre-Reinforced Polymer Reinforcing Bars in Normal and Self-Consolidating Concrete," ACl Material Journal, V.116, No. 3, May 2019, doi:10.14359/51714459. 